\title{
Effects of returning NF concentrate on the MBR-NF process treating antibiotic production wastewater
}

\author{
Kun $\mathrm{Li}^{1,2,3}$ • Yutao Cheng ${ }^{1,2,3,4}$ • Jianxing Wang ${ }^{1,2,3}$. Junya Zhang ${ }^{1,2,3}$ • Jibao Liu ${ }^{1,2,3}$. \\ Dawei $\mathrm{Yu}^{1,2,3} \cdot$ Mingyue $\mathrm{Li}^{5}$ • Yuansong $\mathrm{Wei}^{1,2,3}$
}

Received: 20 November 2015 / Accepted: 11 March 2016/Published online: 22 March 2016

(C) Springer-Verlag Berlin Heidelberg 2016

\begin{abstract}
The optimization of the nanofiltration (NF) concentrate backflow ratio $\left(R_{\mathrm{cb}}\right)$ and the influence of the NF concentrate on the performance of membrane bioreactornanofiltration (MBR-NF) process treating antibiotic production wastewater were investigated on a laboratory scale. The $R_{\mathrm{cb}}$ was optimized at $60 \%$ based on the removal rates of chemical oxygen demand (COD) and $\mathrm{NH}_{4}{ }^{+} \mathrm{N}$ by MBR. Data analyses indicated that salinity brought by NF concentrate is the major driver leading to the decrease of sludge activity, especially at a high $R_{\mathrm{cb}}$. EPS analysis showed that electric conductivity (EC), proteins in soluble microbial products (SMP), and SMP brought by NF concentrate are the dominant factors causing the severe membrane fouling in MBR. Furthermore, undegradable substances including fulvic acid-like and humic acid-like compounds accumulated in NF
\end{abstract}

Responsible editor: Angeles Blanco

Kun Li and Yutao Cheng contributed equally to this work.

Electronic supplementary material The online version of this article (doi:10.1007/s11356-016-6467-x) contains supplementary material, which is available to authorized users.

Yuansong Wei

yswei@rcees.ac.cn

1 State Key Joint Laboratory of Environmental Simulation and Pollution Control, Research Center for Eco-Environmental Sciences, Chinese Academy of Sciences, Beijing 100085, China

2 Beijing Key Laboratory of Industrial Wastewater Treatment and Reuse, Research Center for Eco-Environmental Sciences, Chinese Academy of Sciences, Beijing 100085, China

3 University of Chinese Academy of Sciences, Beijing 100049, China

4 CCID Consulting Co., Ltd., Beijing 100048, China

5 Wuxi Fortune Pharmaceutical Co. Ltd., Wuxi 214046, China concentrate showed significant influence on fouling of NF. MBR could well degrade small MW compounds in NF concentrate, which confirmed the enhancement of organic removal efficiency by recycling the NF concentrate to MBR. The MBR-NF process showed a relatively stable performance at the $R_{\mathrm{cb}}$ of $60 \%$ (volume reduction factor $(\mathrm{VRF})=5$ ), and the NF permeate could satisfy the water quality standard for fermentation process with a water recovery rate of $90.9 \%$.

Keywords Membrane bioreactor · Nanofiltration . Concentrate backflow ratio $\cdot$ Antibiotic production wastewater - Water reuse

\section{Introduction}

China is one of the world largest producers and consumers of antibiotics, and a great amount of antibiotic production wastewater is generated by the pharmaceutical industry every year (Guo et al. 2012). Antibiotic production wastewater is known as a special kind of wastewater containing complicated components with low biodegradability and exhibiting large fluctuations in both water quality and quantity, which would cause great harm to the environment and human health if discharged directly without proper treatment (Cetecioglu 2014; Le-Minh et al. 2010; Li et al. 2014; Michael et al. 2013; Yu et al. 2014). The inhibitory compounds such as antibiotic residues and high salinity in the wastewater hinder the microorganism activity of biochemical treatment process, lower the treatment efficiency, or even cause the failure of treatment process (Cheng et al. 2015; Gutierrez et al. 2002; Huang et al. 2006). Conventional biological treatment processes treating antibiotic production wastewater not only feature a long process line and high cost but also have difficulties meeting the increasingly stringent requirements of discharge standards (Larsson et al. 2007; Li 
2002; Yu et al. 2014). Furthermore, the reclamation of antibiotic production wastewater is also a cause for concern because of the potential economical advantages, while relatively few studies regarding applications have been carried out.

Membrane technologies, such as microfiltration (MF), ultrafiltration (UF), nanofiltration (NF), and reverse osmosis (RO), have been widely applied in wastewater treatment and reuse (Alturki et al. 2010; García-Figueruelo et al. 2008; Jacob et al. 2010; Lau and Ismail 2009). Considering the large pore size of MF and UF which lead a low rejection rate of micropollutants in the wastewater, many studies turned their focus on NF and RO for the applications in the advanced treatment and reclamation of industrial wastewater because of their high efficiency in desalination and steady performance (Al-Rifai et al. 2011; Andrade et al. 2014; Baudequin et al. 2014; Michael et al. 2013; Ravikumar et al. 2014). As a promising technique with broad prospects in the application of wastewater treatment and water reuse, NF could perform high efficiency in the removal of trace-level organic compounds and multivalent ions (Wei et al. 2010). Moreover, NF also shows some advantages compared to RO, especially when both of their permeates can meet the discharge standards or even the recycle water quality standard for industrial uses (Kappel et al. 2014; Ravikumar et al. 2014). For example, the operational pressure for NF is generally much lower than that for RO, equaling cheaper capital and operational costs, although RO provides better performance in rejection of monovalent ions and organic matters with molecular weight (MW) below 1000 Da (Salehi 2014).

It is generally believed that an appropriate pretreatment process could be a key factor for the steady performance of NF or RO in wastewater treatment, especially the sort of wastewater with high contents of organic matters, total dissolved solids (TDS), and suspended solids (SS) (Alturki et al. 2010; Huang et al. 2009; Jacob et al. 2010; Ordóñez et al. 2011). It was found that the deployment of MBR as a pretreatment prior to $\mathrm{NF} / \mathrm{RO}$ could effectively reduce the membrane fouling of NF/RO. The biodegradation and filtration by MBR significantly reduce the organic content and SS in the wastewater, which create ideal pretreatment conditions for nanofiltration (Andrade et al. 2014; Jacob et al. 2010; Judd 2010). More importantly, the combination of membrane bioreactor (MBR) and NF/RO has shown significant complementary effect on the pollutants removal efficiencies of both MBR and NF/RO, which makes the hybrid dual membrane system an effective method for the advanced treatment and reclamation of industrial wastewater (Alturki et al. 2010; Andrade et al. 2014; Cheng et al. 2015; Chon et al. 2012; Jacob et al. 2010; Kappel et al. 2013; Ordóñez Sanz et al. 2010). However, the feasibility of the hybrid membrane system in the application of industrial wastewater reclamation remains largely unconfirmed (Alturki et al. 2010), indicating that there are still some problems to be solved before drawing a conclusion.

One of the existing problems for MBR-NF process is the treatment of NF concentrate with a great deal of recalcitrant contaminants, and researchers tried different methods to solve it (Huang et al. 2015; Kappel et al. 2014; Liu et al. 2014; Van der Bruggen et al. 2008; Yaman et al. 2015). To improve treatment efficiency and water recovery of the system, Rautenbach and Mellis (1994) made the first attempt who returned the NF concentrate back to the bioreactor for the advanced treatment of landfill leachate. The high salinity of NF concentrate flowed back to the MBR will inevitably cause the increase of salinity in the long term, which would influence the sludge characteristics and membrane fouling of MBR as demonstrated by other researchers (Joss et al. 2011; Kappel et al. 2014). Nevertheless, the effect of NF concentrate at diffident backflow ratios $\left(R_{\mathrm{cb}} \mathrm{s}\right)$ remains unclear while the suitable VRF for NF concentrate also needs some attention. In addition, few studies (Wang et al. 2015; Wang et al. 2014) were reported working on the advanced treatment and reclamation of the real antibiotic production wastewater by the MBR-NF process. Further research on the parameter optimization and mechanism study for the application of the MBRNF process in antibiotic production wastewater treatment are imperatively needed. Therefore, the purpose of this study was to obtain an optimized $R_{\mathrm{cb}}$ at an appropriate VRF of NF concentrate for the steady performance of the MBR-NF process with a high water recovery rate and investigate the influence of NF concentrate on the performances and membrane fouling conditions of both the MBR and the NF units in the hybrid dual membrane system.

\section{Materials and methods}

\section{Wastewater characteristics}

The feed water of MBR was the effluent of anaerobic process from a wastewater treatment station of a pharmaceutical company producing spiramycin in Wuxi, China. The COD of the raw wastewater and the anaerobic digestion effluent of antibiotic production wastewater are 6790 and $1460 \mathrm{mg} / \mathrm{L}$, respectively, and other detailed characteristics are listed in Table S1 (Supplementary information (SI)).

\section{MBR-NF process}

A schematic of the lab-scale MBR-NF process in this study is given in Fig. S1 (SI), while the membrane characteristics of MBR and NF are summarized in Table S2 (SI). The MBR incorporated two flat-sheet membrane modules (SINAP-10, pore size $\leq 0.1 \mu \mathrm{m}$, SINAP Membrane S\&T Co., Shanghai, China) with an effective working volume of 100 L. Aerated 
pipes were installed at the bottom of membrane module with a flux of $60 \mathrm{~L} /\left(\min \mathrm{m}^{2}\right)$ to control the membrane fouling by inducing a cross-flow velocity along the membrane surface. Considering the inhibition of antibiotic production wastewater on the sludge activity, no sludge was discharged during the operational duration. Sludge losses from the MBR were mainly due to sampling, and the solid retention time (SRT) was around 600 days. The hydraulic retention time (HRT) of MBR was set to $36 \mathrm{~h}$ according to our former study (Cheng et al. 2012). The MBR effluent was drawn via a peristaltic pump (Baoding Longer Precision Pump Co., USA; model BT6002J; pump head YZ1515X) at an 8-min period with 6-min on and 2-min off controlled by a timer. The transmembrane pressure (TMP) and $\mathrm{pH}$ values were monitored and recorded daily, and $1 \mathrm{~mol} / \mathrm{L} \mathrm{Na} \mathrm{CO}_{3}$ solution was added to maintain the $\mathrm{pH}$ value because of the alkalinity consumption by ammonia oxidation in MBR. The operating conditions of MBR are summarized in Table S3 (SI).

The NF unit consists of three spiral wound NF modules (Desal 5 DK 1812, molecular weight cutoff 150 300 Da, GE OSMONICS, USA) with a centrifugal pump, and the detailed operating conditions are listed in Table S4 (SI). NF membranes were cleaned by $\mathrm{NaOH}$ solution at $\mathrm{pH}=12$ firstly and then by $\mathrm{HCl}$ solution at $\mathrm{pH}=2$ to remove pollutants on the membrane surface. After that, membranes were soaked in deionized water for $12 \mathrm{~h}$ and pressurized with deionized water at $12 \mathrm{bar}$ for another $12 \mathrm{~h}$ to assure a steady structure before each experiment.

\section{Experimental conditions}

The MBR was operated in continuous mode with the antibiotic production wastewater feeding in continuously while the NF was operated in batch mode because of the wastewater source limitation under laboratory conditions. The MBR effluent was stored in a separation tank, then pumped into the $\mathrm{NF}$ unit through a 5- $\mu \mathrm{m}$ mesh filter. The NF concentrate returned based on the $R_{\mathrm{cb}}$ was thoroughly mixed with antibiotic production wastewater before recycled to the MBR while the NF permeate was discharged or reused.

The MBR was operated in two stages. The selection of membranes and the optimization of HRT were conducted in the first stage which lasted for 150 days with no NF concentrate returned (detailed in Cheng et al. 2012). In the second stage, the MBR was operated at different $R_{\mathrm{cb}} \mathrm{S}$ with a fixed VRF $(\mathrm{VRF}=5)$ to attain an appropriate $R_{\mathrm{cb}}$ based on the optimized parameters, while the performance of NF unit at different VRFs (from 2 to 5 ) with the variations of $R_{\mathrm{cb}}$ was investigated. The NF concentrate backflow ratio $\left(R_{\mathrm{cb}}\right)$ was defined as the backflow of NF concentrate divided by the NF concentrate produced, and it was selected as 40, 60, 80, and $90 \%$. Each period of $R_{\mathrm{cb}}$ lasted 13 days, except for 18 days at the $R_{\mathrm{cb}}$ of $90 \%$. The characteristics of NF concentrate at the end of each period were listed in Table S5 (SI). The $R_{\mathrm{cb}}$ was calculated by Eq. (1):

$R_{c b}=\frac{V_{c b}}{V_{c}}$

where $R_{\mathrm{cb}}$ is the NF concentrate backflow ratio, $\%$; $V_{\mathrm{cb}}$ is the volume of NF concentrate returned to the MBR, L; and $V_{\mathrm{c}}$ is the volume of the NF concentrate produced, $\mathrm{L}$.

The NF concentrate was returned to the MBR in a continuous mode at a flow rate varied with $R_{\mathrm{cb}} \mathrm{S}$, which replaced part of the treatment capacity to enhance the water recovery. The flow rate of NF concentrate returned $\left(Q_{\mathrm{cb}}\right)$ was calculated by Eq. (2):

$Q_{c b}=Q_{c} \cdot R_{c b}$

where $Q_{\mathrm{cb}}$ and $Q_{\mathrm{c}}$ are the flow rate of the NF concentrate returned and the NF concentrate produced, $\mathrm{L} / \mathrm{h}$, respectively.

Samples of MBR sludge mixture and MBR permeate were taken for analysis every 3 days during each period. To investigate the impact of NF concentrate on the performance of MBR, the steady state of MBR based on the operational conditions optimized in the first stage (i.e., first period in the second stage) was selected as the control and membranes in MBR were chemically cleaned by $5000 \mathrm{mg} / \mathrm{L}$ (as $\mathrm{Cl}_{2}$ ) $\mathrm{NaOCl}$ solution and afterwards by $1000 \mathrm{mg} / \mathrm{L}$ citric acid solution after the first stage to eliminate the fouling accumulated that might impact the operating conditions in the second stage.

The NF unit was conducted in the concentration mode of filtration (CMF), which means the NF permeate is discharged or collected while NF concentrate is recycled to the feed tank, and components in the NF concentrate are concentrated with the operational duration. VRF was used to describe the extent of concentration in the CMF test (García-Figueruelo et al. 2008; Jacob et al. 2010), and it was calculated using Eq. (3):

$\mathrm{VRF}=\frac{V f}{V c}$

where $V_{\mathrm{f}}$ and $V_{\mathrm{c}}$ are the initial volume of the NF feed and the volume of NF concentrate produced, L, respectively.

To investigate the influence of VRF on the performance of $\mathrm{NF}$, the NF unit was maintained for $2 \mathrm{~h}$ at VRFs of 2, 3, and 4, respectively, and then operated at a fixed VRF of 5 until the end of each period of $R_{\mathrm{cb}}$. The initial volume of the feed was concentrated to the volume of the NF concentrate according to the pre-set VRF, then the MBR effluent was fed into the feed tank of NF with a flow rate $\left(Q_{\mathrm{i}}\right)$ calculated by Eq. (4) to maintain the water level in the feed tank:

$Q_{i}=Q_{c} \cdot \mathrm{VRF}$

where $Q_{\mathrm{i}}$ is the flow rate of the NF influent, $\mathrm{L} / \mathrm{h}$ 
The NF concentrate was recycled to the feed tank of NF to restore the feed volume to the initial value, and then the NF concentrate was collected in a separate tank. The NF unit was firstly maintained at the VRF of 2, and then the VRF was increased to the values in order of 3, 4, and 5. Similar steps were followed at different VRFs as mentioned above to maintain the water level in the feed tank of NF. The NF concentrate stored at the VRF of 5 was partly returned to the MBR according to the pre-set $R_{\mathrm{cb}}$. The fluctuation of NF concentrate flux and permeate flux were monitored to evaluate the flux decline rate of NF permeate, and samples were taken at the end of each VRF period to evaluate the performance of NF at different VRFs with a certain $R_{\mathrm{cb}}$.

The water recovery rate of the MBR-NF process was calculated using Eq. (5):

$R \mathrm{w}=\frac{V p}{V f} \times 100 \%$

where $R_{\mathrm{w}}$ is the water recovery rate, $\%$; and $V_{\mathrm{p}}$ is the volume of the NF permeate produced, L.

The total filtration resistance $\left(R_{\mathrm{t}}\right)$ was calculated using Eq. (6):

$R \mathrm{t}=\frac{T M P}{\mu \cdot J}$

where $R_{\mathrm{t}}$ is the filtration resistance, $\mathrm{m}^{-1}$; TMP is the transmembrane pressure, $\mathrm{Pa}$; $J$ is the permeate flux, $\mathrm{L} /\left(\mathrm{m}^{2} \mathrm{~s}\right)$; and $\mu$ is the permeate viscosity, Pa s.

\section{Analytical methods}

The concentrations of COD, $\mathrm{NH}_{4}{ }^{+}-\mathrm{N}, \mathrm{pH}, \mathrm{MLSS}$, and MLVSS were determined according to Chinese NEPA standard methods (Chinese NEPA 2002). Dissolved oxygen (DO) concentration in MBR was detected by a portable meter and an optical probe (WTW Multi 3410 Multiparameter Meter, Weilheim, Germany). Specific oxygen uptake rate (SOUR) tests of mixed liquor were conducted periodically using a Winkler bottle method as introduced in literatures (Han et al. 2005; Jubany et al. 2005). Firstly, $500 \mathrm{~mL}$ mixed liquor from the MBR was added to the bottle and aerated until the DO reached constant level. Then oxygen measurements were acquired every $4 \mathrm{~s}$ until the DO decreased by $1.5 \mathrm{mg} \mathrm{O}_{2} \mathrm{~L}^{-1}$ or during a maximum period of $8 \mathrm{~min}$. The SOUR value was calculated by Eq. (7):

$\mathrm{SOUR}=\frac{d C_{\mathrm{O} 2} / d t}{\mathrm{MLVSS}}$

where SOUR is the specific oxygen uptake rate, $\mathrm{mgO}_{2}$ $\mathrm{gVSS}^{-1} \mathrm{~h}^{-1} ; \mathrm{C}_{\mathrm{O} 2}$ is the oxygen concentration, $\mathrm{mg} / \mathrm{L} ; d C_{\mathrm{O} 2} /$ $d t$ is the dissolved oxygen consumption rate, $\mathrm{mg} \mathrm{O}_{2}(\mathrm{~L} \mathrm{~min})^{-1}$; MLVSS is the mixed liquor volatile suspended solids, mg/L.
The total organic carbon (TOC) was determined by a TOCVCPH analyzer (Shimadzu, Japan). The electric conductivity was measured with a conductivity meter (HI4321, Hanna, Italy). A turbidity meter (Turb 550, WTW, Germany) was used to measure the turbidity. A fluorescence spectrophotometer (F-7000, Hitachi, Japan) and a gel permeation chromatography (GPC)-UV detection with a high performance liquid chromatography (HPLC) system (Breeze 1525, Waters Co, USA) were used to investigate the major components and the complexity of organic matters in water samples.

Scanning electron microscopy with energy dispersive Xray spectroscopy (SEM-EDX) (S-3000N, Hitachi, Japan) was used to observe the variations of microbe species and inorganic salts. The dewatering of sludge was measured as capillary suction time (CST) using a Capillary Suction Timer (Triton, Model 304 M, UK) and the method details were listed in a reference (Ye et al. 2011).

The method for the extraction of extracellular polymeric substance (EPS) by using a cation exchange resin (CER) has been introduced elsewhere (Lin et al. 2011), and the detailed procedures were described in (Yuan and Wang 2012). The amounts of polysaccharides and proteins in EPS were measured by colorimetric methods (Dubois et al. 1956; Lowry et al. 1951).

\section{Statistical analysis}

Spearman's rank correlations analysis was carried out using SPSS version 18.0 software (SPSS Inc., Chicago, USA). The relationships among TMP, electric conductivity (EC), and the components of EPS in water and sludge samples at different $R_{\mathrm{cb}} \mathrm{S}(\mathrm{VRF}=5)$ were analyzed by Spearman analysis. The Spearman's coefficient $\left(\mathrm{r}_{\mathrm{s}}\right)$ is always between -1 and +1 , where -1 means a perfect negative correlation and +1 a perfect positive correlation, while 0 means absence of relationship. Correlations are considered statistically significant at a $95 \%$ confidence interval ( $p$ value $<0.05$, two-tailed). Principal component analysis (PCA) (CANOCO for Windows, Microcomputer Power, USA) was used to investigate the influence of NF concentrate on the activity of MBR sludge and the connections between EPS components and membrane fouling in MBR combined with results from Spearman's rank correlation tests.

\section{Results and discussion}

\section{MBR performance at different NF concentrate backflow ratios with the $V R F=5$}

$\mathrm{COD}$ and $\mathrm{NH}_{4}^{+}-\mathrm{N}$ removals

As summarized in Table 1 , the COD removal rates $\left(R_{\mathrm{COD}} \mathrm{S}\right)$ of MBR at most $R_{\mathrm{cb}} \mathrm{S}$ were lower than that of the control except at 
Table $1 \mathrm{COD}$ and $\mathrm{NH}_{4}{ }^{+} \mathrm{N}$ removal of MBR at different $\mathrm{R}_{\mathrm{cb}} \mathrm{S}$ (Average $\pm \mathrm{SD}, n=4$ )

\begin{tabular}{|c|c|c|c|c|c|c|}
\hline & \multicolumn{2}{|l|}{ Influent (mg/L) } & \multicolumn{2}{|l|}{ Effluent (mg/L) } & \multicolumn{2}{|c|}{ Removal rate $(\%)$} \\
\hline & COD & $\mathrm{NH}_{4}^{+}-\mathrm{N}$ & COD & $\mathrm{NH}_{4}^{+}-\mathrm{N}$ & COD & $\mathrm{NH}_{4}^{+}-\mathrm{N}$ \\
\hline $\begin{array}{l}\text { Without } \\
\text { backflow }\end{array}$ & $850 \pm 137.84$ & $349.45 \pm 15.06$ & $327.5 \pm 43.49$ & $8.23 \pm 1.25$ & $60.88 \pm 7.21$ & $97.65 \pm 0.29$ \\
\hline $\begin{array}{l}40 \% \\
\text { backflow }\end{array}$ & $787.5 \pm 36.86$ & $330.70 \pm 18.26$ & $355 \pm 37.86$ & $11.38 \pm 9.28$ & $54.94 \pm 3.89$ & $96.59 \pm 2.75$ \\
\hline $\begin{array}{l}60 \% \\
\text { backflow }\end{array}$ & $1052.5 \pm 367.82$ & $285.09 \pm 36.53$ & $277.5 \pm 69.94$ & $7.53 \pm 1.43$ & $71.52 \pm 11.95$ & $97.28 \pm 0.82$ \\
\hline $\begin{array}{l}80 \% \\
\text { backflow }\end{array}$ & $892.5 \pm 105.95$ & $296.05 \pm 6.71$ & $457.5 \pm 28.72$ & $10.62 \pm 2.36$ & $48.16 \pm 7.34$ & $96.41 \pm 0.81$ \\
\hline $\begin{array}{l}90 \% \\
\text { backflow }\end{array}$ & $1310 \pm 144.45$ & $275.66 \pm 28.86$ & $677.5 \pm 104.68$ & $13.22 \pm 4.23$ & $48.47 \pm 2.54$ & $95.25 \pm 1.18$ \\
\hline
\end{tabular}

the $R_{\mathrm{cb}}$ of $60 \%$. Almost all the COD of MBR effluent were below the limit of sewer discharge $(500 \mathrm{mg} / \mathrm{L})$ except at the $R_{\mathrm{cb}}$ of $90 \%(677.5 \mathrm{mg} / \mathrm{L})$. As the $R_{\mathrm{cb}}$ increased from 0 to $40 \%$, the $R_{\mathrm{COD}}$ decreased from 60.88 to $54.94 \%$ which indicated that the high salinity and refractory compounds in NF concentrate might have caused inhibitory effect on the metabolic activity of activated sludge as mentioned in other literatures (Rene et al. 2008; Uygur 2006; Yogalakshmi and Joseph 2010). It is interesting to notice that the $R_{\mathrm{COD}}$ climbed up to maximum $(71.52 \%)$ while the COD of MBR effluent decreased to minimum $(277.5 \mathrm{mg} / \mathrm{L})$ at the $R_{\mathrm{cb}}$ of $60 \%$. This phenomenon suggests that the activated sludge in MBR adapted to the salt induced stress brought by the NF concentrate after acclimatization, or even stimulated to a higher COD removal efficiency (Jang et al. 2014; Rene et al. 2008). However, when the $R_{\mathrm{cb}}$ increased to 80 and $90 \%$, the $R_{\mathrm{COD}}$ decreased to approximately $48 \%$, indicating that it might need a longer time for the activated sludge to readapt to the environmental conditions at high $R_{\mathrm{cb}} \mathrm{s}$. In contrast to the variation of $R_{\mathrm{COD}}$, the $\mathrm{NH}_{4}{ }^{+}-\mathrm{N}$ removal rate $\left(R_{\mathrm{NH} 4+}\right)$ was steadily higher than $95 \%$ throughout the entire experiment, and the $\mathrm{NH}_{4}{ }^{+}-\mathrm{N}$ concentration in the effluent remained below $14 \mathrm{mg}$ / L. Similar to the tendency of COD removal efficiency, the optimum efficiency of $\mathrm{NH}_{4}{ }^{+}-\mathrm{N}$ removal was also achieved at the $R_{\mathrm{cb}}$ of $60 \%$. Based on the results and discussions above, it is reasonable to consider that the optimized value of $R_{\mathrm{cb}}$ should be chosen at $60 \%$.

\section{Flux and membrane fouling of $M B R$}

The membrane critical flux was $12.24 \mathrm{~L} \cdot \mathrm{m}^{-2} \cdot \mathrm{h}^{-1}$ according to the results of previous tests (Cheng et al. 2012), and a subcritical flux between $6.4 \mathrm{~L} \cdot \mathrm{m}^{-2} \cdot \mathrm{h}^{-1}$ and $7.8 \mathrm{~L} \cdot \mathrm{m}^{-2} \cdot \mathrm{h}^{-1}$ was selected. The variations of TMP and membrane resistance are shown in Fig. 1. The MBR was stable with a flux around $7.8 \mathrm{~L} \cdot \mathrm{m}^{-2} \cdot \mathrm{h}^{-1}$ while the TMP hardly changed during the
Fig. 1 Influence of NF concentrate on membrane fouling in MBR

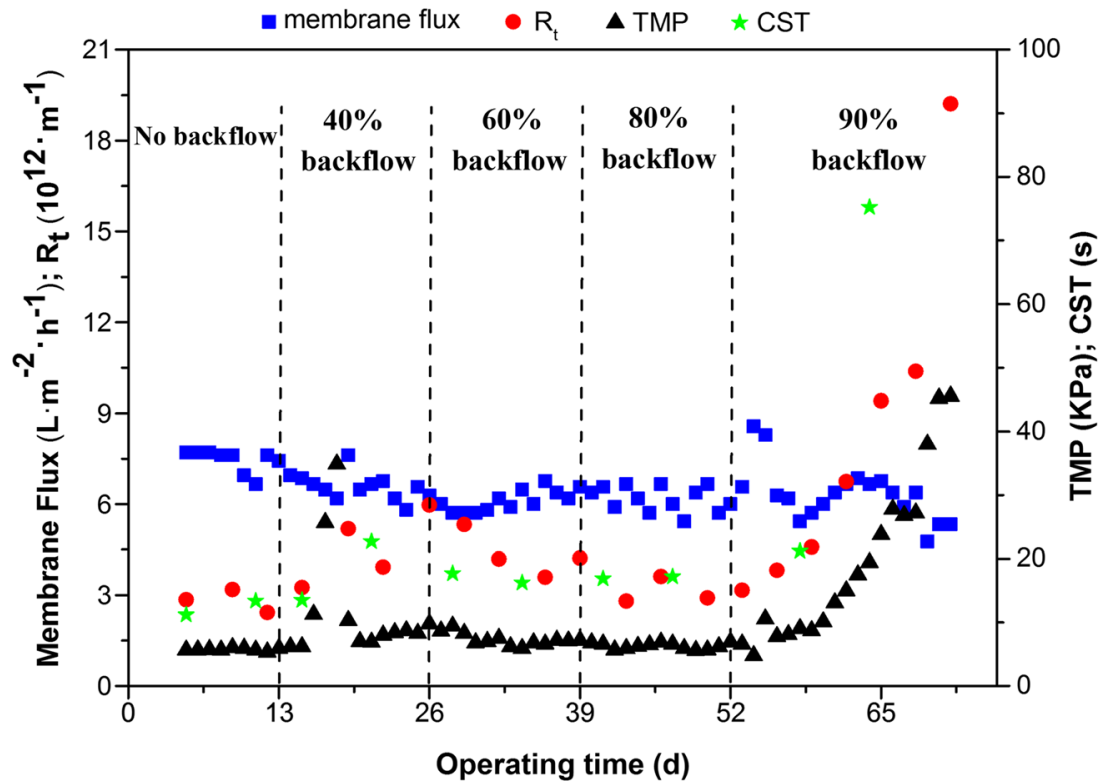


period with no NF concentrate returned. An unexpected rapid increase in TMP showed on the third day of the period at the $R_{\mathrm{cb}}$ of $40 \%$, but the TMP returned to normal by adjusting the flux to $6.4 \mathrm{~L} \cdot \mathrm{m}^{-2} \cdot \mathrm{h}^{-1}$ after a 4 -h no-effluent aeration. No significant membrane fouling was observed along with the $R_{\mathrm{cb}}$ increased from 0 to $80 \%$ according to a relatively low TMP. However, a sharp rise of TMP appeared at the $R_{\mathrm{cb}}$ of $90 \%$, indicating the occurrence of serious membrane fouling related to the high salinity and refractory organics brought by the NF concentrate (Rene et al. 2008; Uygur 2006; Yogalakshmi and Joseph 2010). As shown in Fig. 1, the variation of CST was consistent with the variations of TMP and the membrane resistance. It is well known that the CST is consistent with the sludge dewaterability and filterability. Many researchers (AlHalbouni et al. 2008; Pan et al. 2010; Wang et al. 2006; Wu et al. 2007) have proved that a high CST implies a high bound water content and bad filterability of sludge which could possibly lead to serious membrane fouling, and thus it was reasonable to set CST as an indicator of membrane fouling.

\section{SOUR and MLVSS/MLSS ratio}

The MLVSS/MLSS ratio $(f)$ and the specific oxygen uptake rate (SOUR) were selected as the indicators of the sludge activity in MBR (Yang et al. 2010). Variations of $R_{\mathrm{cb}}$, food to microorganism ratio $(\mathrm{F} / \mathrm{M})$, organic removal loading rate (ORLR), and EC were analyzed to investigate the influence of the NF concentrate on the MBR sludge activity during different operational periods. A scatter diagram of operational parameters is shown in Fig. 2a, the repeated rising and declining trends of both the $f$ and the SOUR values indicated that the MBR sludge had undergone a process of decomposition and regrowth. The MBR sludge presented a delayed response to the change of $R_{\mathrm{cb}}$, and it could finally well adapt to the environmental changes caused by the NF concentrate when the operational duration was long enough (Jang et al. 2014; Rene et al. 2008).

No sludge was discharged during the experiment with the $R_{\mathrm{cb}}$ increased from 0 to $90 \%$, which unavoidably led to a salt accumulation in MBR (Table S3 and Table S5, SI). The EDX results (Table S6, SI) also confirmed the salt accumulation, as the contents of $\mathrm{Na}, \mathrm{Mg}, \mathrm{Al}, \mathrm{S}$, and $\mathrm{Ca}$ were more than doubled while the content of $\mathrm{C}$ decreased noticeably from 67.05 to $55.33 \%$. Results of PCA are shown in Fig. $2 \mathrm{~b}, R_{\mathrm{cb}}$ showed a perfect negative effect on $f$ according to the distribution of sample points and the included angle between arrow directions of $R_{\mathrm{cb}}$ and $f$. Projection points of samples on the axes of $R_{\mathrm{cb}}$ and $f$ indicated that the sludge activity decreased with the increase of $R_{\mathrm{cb}}$. Projection lines of EC, F/M, and ORLR on the axis of $f$ showed that $\mathrm{EC}$ had the strongest negative correlation with $f$, indicating that salinity was the dominant factor for the decrease of sludge activity. Meanwhile, F/M and ORLR showed some positive correlations with SOUR, while
EC had little impact on SOUR. A Spearman's rank correlation test was applied to analyze the correlations among these parameters, and the result confirmed the significant negative correlation $\left(r_{\mathrm{s}}=-0.47, p\right.$ value $\left.<0.05\right)$ between $\mathrm{EC}$ and $f$. SEM images of sludge (Fig. S2, SI) implied a morphological change at the $R_{\mathrm{cb}}$ of $90 \%$, which supported the conclusion that the high salinity in NF concentrate caused negative impact on sludge microbes. Results and discussions above demonstrated that salinity brought by the NF concentrate is the key factor affecting the sludge activity, especially at a high $R_{\mathrm{cb}}$, which is consistent with the conclusions of other researchers (Joss et al. 2011; Kappel et al. 2014).

\section{EPS analysis}

Concentrations of proteins and polysaccharides, which were found to be the major constituents in EPS (Wang et al. 2009), varied differently with the increase of $R_{\mathrm{cb}}$ (Table $\mathrm{S} 7$ (SI) and Fig. 3a). The proteins content increased in both the influent and effluent with the increase of $R_{\mathrm{cb}}$ while its removal rate decreased. It is notable that the polysaccharides content in effluent was higher than that in influent through all periods, while its content in the effluent experienced a process from decrease to increase which might because the microorganisms produced polysaccharides to protect themselves from the environmental pressures such as salinity and biological inhibitors (Zhang et al. 2011).

Based on data shown in Fig. $3 \mathrm{~b}$ and Table S7 (SI), the total specific SMP content rose with the increase of $R_{\mathrm{cb}}$ while the total specific bEPS (bound EPS) and the total EPS experienced a process from decrease to increase. It is noteworthy that the proteins/polysaccharides (PN/PC) ratio showed different variations in SMP and bEPS. The former one showed a gradual increase, while the latter one varied from increase to decrease. Many researchers focused on the relationship between EPS and membrane fouling in MBR, and diffident conclusions came out mainly attributed to the variations of feedwater characteristics and operating conditions. Some researchers (Cho et al. 2005; Liu et al. 2012; Wang et al. 2009; Wang et al. 2011) found that bEPS especially the loosely bound EPS (lbEPS) played a more significant role in membrane fouling, while others (Meng et al. 2009) considered that the soluble EPS (or SMP) had greater impact on membrane fouling than bEPS. There are also some debates between proteins and polysaccharides in EPS for which one have more contribution on membrane fouling (Sweity et al. 2011; Wang et al. 2011).

To uncover the relationships of TMP, EC, and the components of EPS in water and sludge samples at different $R_{\mathrm{cb}} \mathrm{S}$, PCA and Spearman correlation analyses were performed. Different from previously reported results, correlations between EPS and membrane fouling in MBR with the backflow of NF concentrate showed some new features. EC, proteins 
Fig. 2 Influence of NF concentrate on the activity of MBR sludge: a scatter diagram of SOUR, $f, \mathrm{~F} / \mathrm{M}, \mathrm{ORLR}$, and $\mathrm{EC} ; \mathbf{b}$ PCA ordination diagram (biplot) based on parameters in Fig. 2a. Sample points included in the same circle are in the same period of a certain $R_{\mathrm{cb}}$
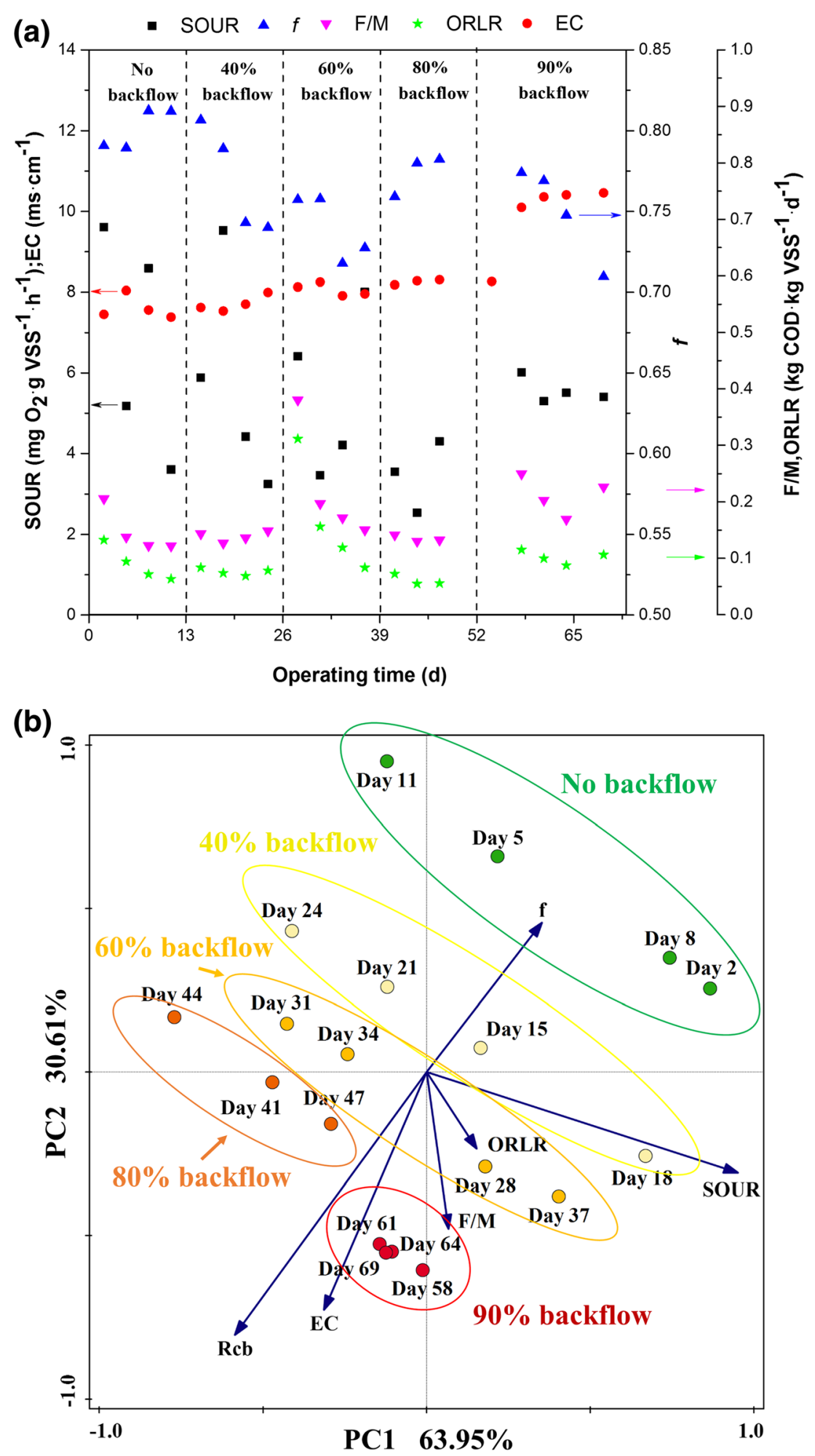

(PN) in SMP, and total specific SMP showed the three longest projection lines on the axis of TMP (Fig. 3c), indicating that these three parameters have strongest correlations with TMP among all factors considered. Furthermore, results of Spearman's rank correlation test proved that EC, PN in SMP, and total specific SMP have significant positive correlations with TMP, i.e., for EC: $r_{\mathrm{s}}=0.535, p$ value $<0.05$; for PN in SMP: $r_{\mathrm{S}}=0.589, p$ value $<0.01$; for total specific

Fig. 3 Influence of NF concentrate on the variations of proteins and polysaccharides in MBR: a water samples, b sludge samples, c PCA ordination diagram (biplot) based on parameters in Fig. 2b. $P N$ proteins, $P C$ polysaccharides 


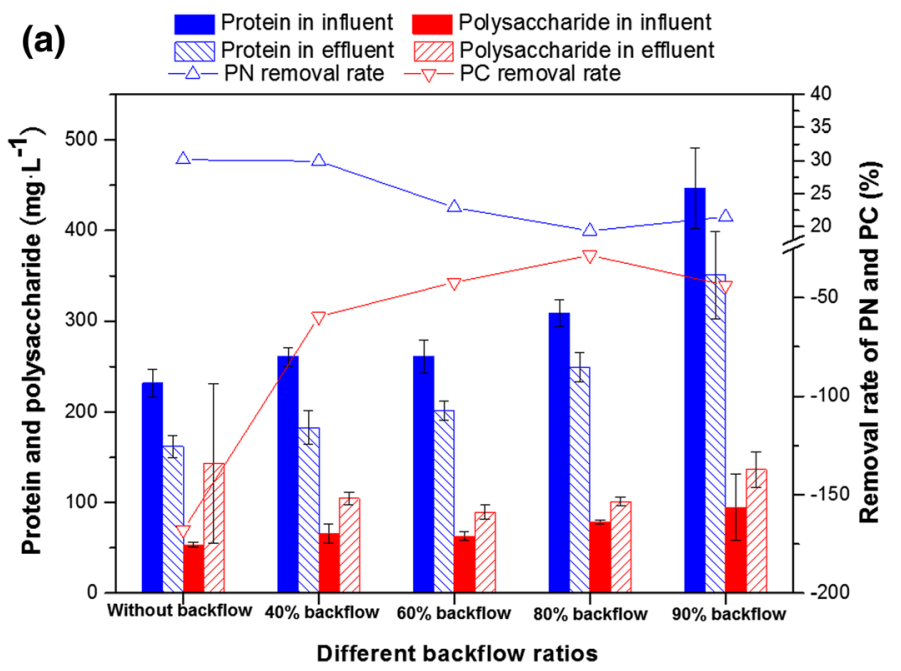

(b)

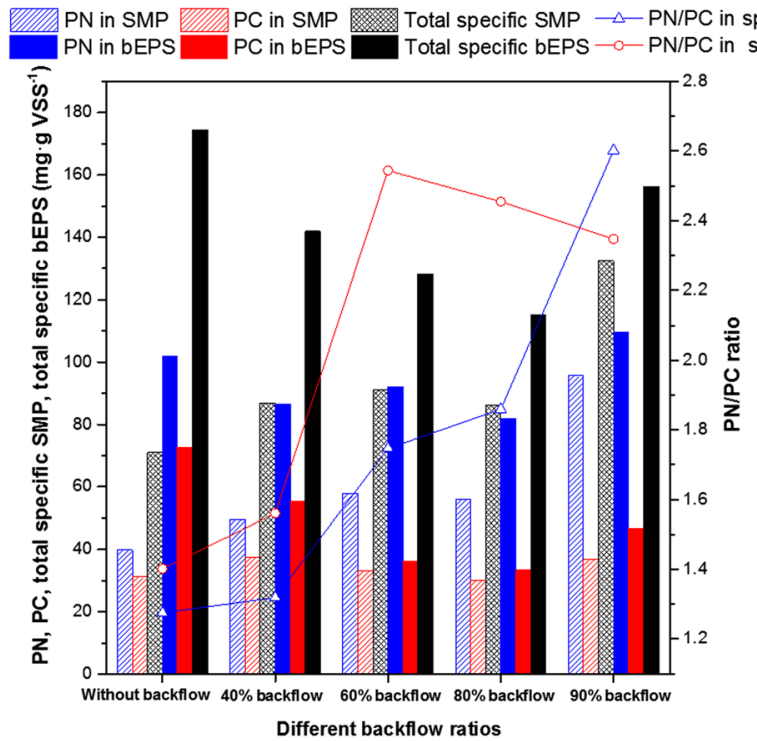

(c)

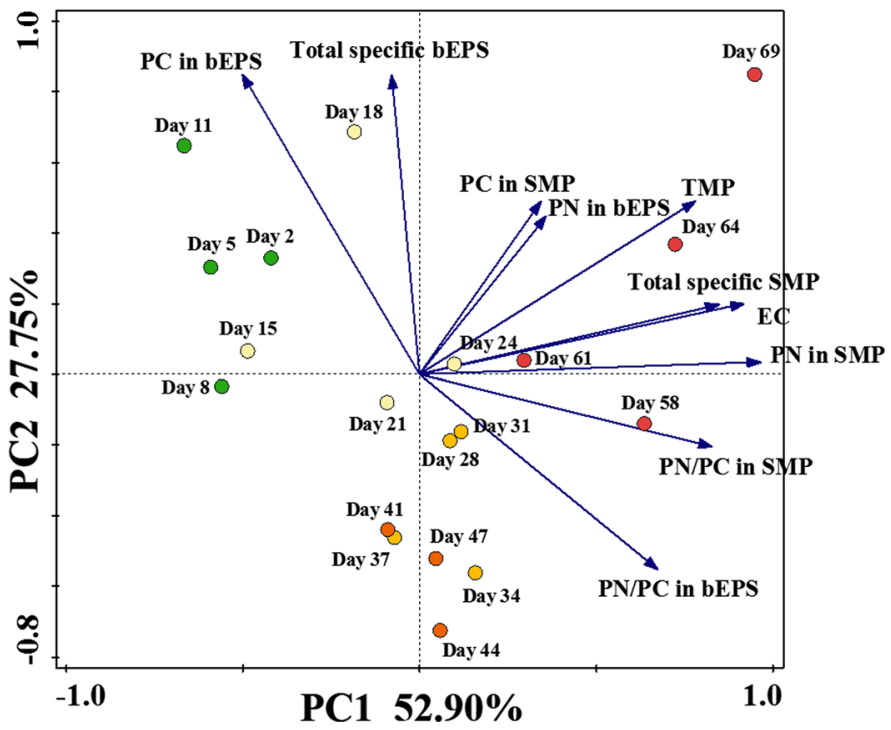


Fig. 4 Fate of ions in the MBR-

NF process $\left(R_{\mathrm{cb}}=60 \%\right)$ : a

monovalent ions, $\mathbf{b}$ multivalent ions (a)
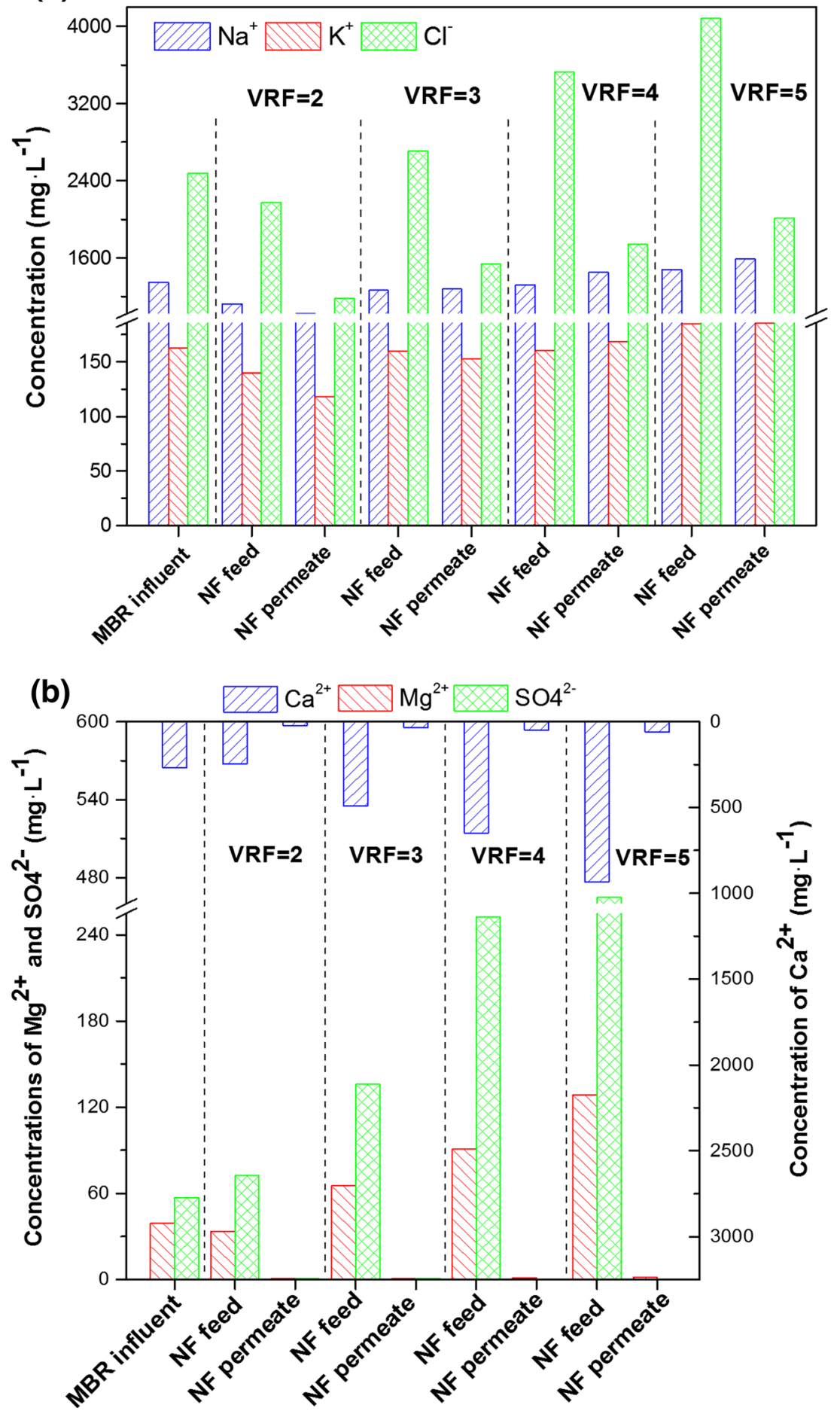

SMP: $r_{\mathrm{s}}=0.709, p$ value $<0.01$, respectively. These results demonstrated that EC, PN in SMP, and total specific SMP are the top three contributors for the membrane fouling in MBR. Sweity et al. (2011) found that a high PN/PC ratio in EPS could reduce fouling; however, both PN/PC in SMP and bEPS showed positive correlations with TMP in this study (Fig. 3c). The bEPS are closely connected to sludge characteristics (Meng et al. 2009), and the variation of bEPS implied a relatively stable status of sludge in MBR (Fig. 3b). Moreover, components of bEPS did not show significant correlations with TMP, indicating that the backflow of NF concentrate could be the real reason why PN in SMP and total specific SMP play more important roles for the membrane fouling in MBR. Thus, it is reasonable to conclude that EC, 
PN in SMP, and SMP brought by NF concentrate are the main causes leading to the severe membrane fouling in MBR.

\section{NF performance at different NF concentrate backflow ratios with the $\mathrm{VRF}=\mathbf{2} \sim 5$}

\section{COD removal}

The influences of $R_{\mathrm{cb}}$ and VRF on the COD removal efficiency are shown in Fig. S3a (SI). Both the COD concentrations in NF feed and NF permeate increased with the increase of $R_{\mathrm{cb}}$ and VRF generally, except that in the NF permeate at $R_{\mathrm{cb}}$ of $80 \%$ which was the lowest among permeate samples at different $R_{\mathrm{cb}} \mathrm{S}$. Organic matters accumulated in NF concentrate with the increase of VRF especially at a high $R_{\mathrm{cb}}$ because of the high retention rate of NF. Overall, the $R_{\mathrm{COD}}$ by NF was kept above $98 \%$ in all periods, while COD in NF permeate remained less than $10 \mathrm{mg} / \mathrm{L}$ except that at the $R_{\mathrm{cb}}$ of $90 \%$. These results proved that the NF unit was relatively stable during the experiment, providing high quality permeate with a high COD removal efficiency.

\section{Salinity removal}

Similar to COD removal, the EC concentrations in NF feed and NF permeate increased with the increase of $R_{\mathrm{cb}}$ and VRF. EC removal rate $\left(R_{\mathrm{EC}}\right)$ of NF was relatively stable around $40 \%$, and it showed a slight increase with the increase of VRF (Fig. S3b, SI). Fate of monovalent and multivalent ions were investigated at the optimized $R_{\mathrm{cb}}(60 \%)(\mathrm{Fig} .4 \mathrm{a}, \mathrm{b}) . \mathrm{K}^{+}$, $\mathrm{Ca}^{2+}, \mathrm{Na}^{+}, \mathrm{Cl}^{-}$, and $\mathrm{SO}_{4}{ }^{2-}$ were found to be the main ions. Removal rate of $\mathrm{Na}^{+}\left(R_{\mathrm{Na}+}\right)$ declined from $9.06 \%(\mathrm{VRF}=2)$ to $-9.87 \%(\mathrm{VRF}=4)$, then increased a little to $-7.34 \%$ $(\mathrm{VRF}=5)$, while that of $\mathrm{K}^{+}\left(R_{\mathrm{K}+}\right)$ showed the same trend. Similar phenomena were studied by other researchers (Cuartas-Uribe et al. 2006; Luo and Wan 2013), and these could be explained by the co-ions competition in the inorganic salt mixtures. Co-ions with less charge and higher mobility are prone to permeate, which always result in a retention decay of monovalent ions, or even a negative retention near neutral $\mathrm{pH}$ (Luo and Wan 2013). The fate of $\mathrm{Cl}^{-}$was much different from that of $\mathrm{Na}^{+}$or $\mathrm{K}^{+}$. The $\mathrm{Cl}^{-}$removal rate $\left(R_{\mathrm{Cl}}\right)$ increased from 45.68 to $50.63 \%$ while both the $\mathrm{Cl}^{-}$concentration in NF influent and permeate increased significantly with the increase of VRF. The like charges repulsion could be the main reason that lead to a higher removal rate for $\mathrm{Cl}^{-}$than that for $\mathrm{Na}^{+}$ though $\mathrm{Na}^{+}$has a slight bigger ionic radius than $\mathrm{Cl}^{-}$(Luo and Wan 2013; Van der Bruggen et al. 2004). Besides, removal rates of $\mathrm{Ca}^{2+}, \mathrm{Mg}^{2+}$, and $\mathrm{SO}_{4}{ }^{2-}$ by $\mathrm{NF}$ remained above 91,98 , and $99 \%$ at all VRFs because of the stronger steric hindrance effect and electrostatic repulsion on multivalent ions (Luo and Wan 2013).

\section{NF permeate flux and water recovery}

The NF permeate flux decline rate increased with the increase of $R_{\mathrm{cb}} \mathrm{S}$ in general (Table S8, SI). Both the $R_{\mathrm{cb}}$ and VRF have great influence on NF membrane fouling, and much higher flux decline rates were observed at the $R_{\mathrm{cb}}$ of $90 \%$ with the VRF of 4 and 5, indicating the salinity and undegradable substances accumulated in the NF concentrate would cause serious membrane fouling of NF. The water recovery rate of the MBR-NF process at the $R_{\mathrm{cb}}$ of $60 \%(\mathrm{VRF}=5)$ was calculated using Eq. (5) (detailed in Fig. S4, SI). The final water recovery rate is $90.9 \%$ which is over $10 \%$ higher than that without the backflow $(80 \%)$. After treated by the MBR-NF process, the NF permeate could satisfy the requirements of water quality for fermentation process (Table S9, SI). These results strongly proved that the MBR-NF process is suitable and beneficial for the advanced treatment and reclamation of antibiotic production wastewater.

\section{Fate of organic contaminants in the MBR-NF process at the $R_{\mathrm{cb}}$ of $60 \%$}

\section{TOC and molecular weight distribution}

TOC of the initial MBR influent and MBR effluent were 229.20 and $126.24 \mathrm{mg} \cdot \mathrm{L}^{-1}(\mathrm{VRF}=5)$, respectively, equaling a removal rate of $44.92 \%$ while the NF unit contributed an excellent removal rate over $98 \%$ at all VRFs (Fig. 5a). TOC of NF concentrate increased significantly with the increase of $\mathrm{VRF}$, and the TOC at $\mathrm{VRF}=5$ was more than triple of the initial value at $\mathrm{VRF}=2$. However, $\mathrm{VRF}$ had little impact on NF permeate with TOC stable at approximately $2 \mathrm{mg} / \mathrm{L}$. These results suggested that the steady performance of NF guarantees the removal efficiency of organic matters by the MBR-NF process with the backflow of NF concentrate, which is in good agreement with results reported in other literatures (Kappel et al. 2014; Wang et al. 2015; Wang et al. 2014).

The MW distribution of organic matters at $\mathrm{VRF}=5$ in the MBR-NF process is shown in Fig. 5b. Two similar distinct peaks were found in MBR samples. The highest intensities were observed in MBR influent (531 and $1706 \mathrm{Da}$ ) and followed by MBR supernatant (541 and $1841 \mathrm{Da}$ ) and MBR effluent (551 and $1807 \mathrm{Da}$ ) attributed to the biodegradation of MBR sludge. Peaks in NF concentrate (123 and 567 Da) showed obvious drift towards lower MW compared to peaks in MBR effluent multiplied by 5 times $(\mathrm{VRF}=5)$, and the peak with lower MW is higher while the other one is lower compared to the reference peaks $(\mathrm{MBR} \times 5)$. This phenomenon could be related to the high shear force caused by centrifugal pump during the filtration process. High MW organics might be easier to absorb onto the membrane while the relatively lower MW ones might be easier to desorb from the membrane surface. Moreover, those small molecules were 
(a)
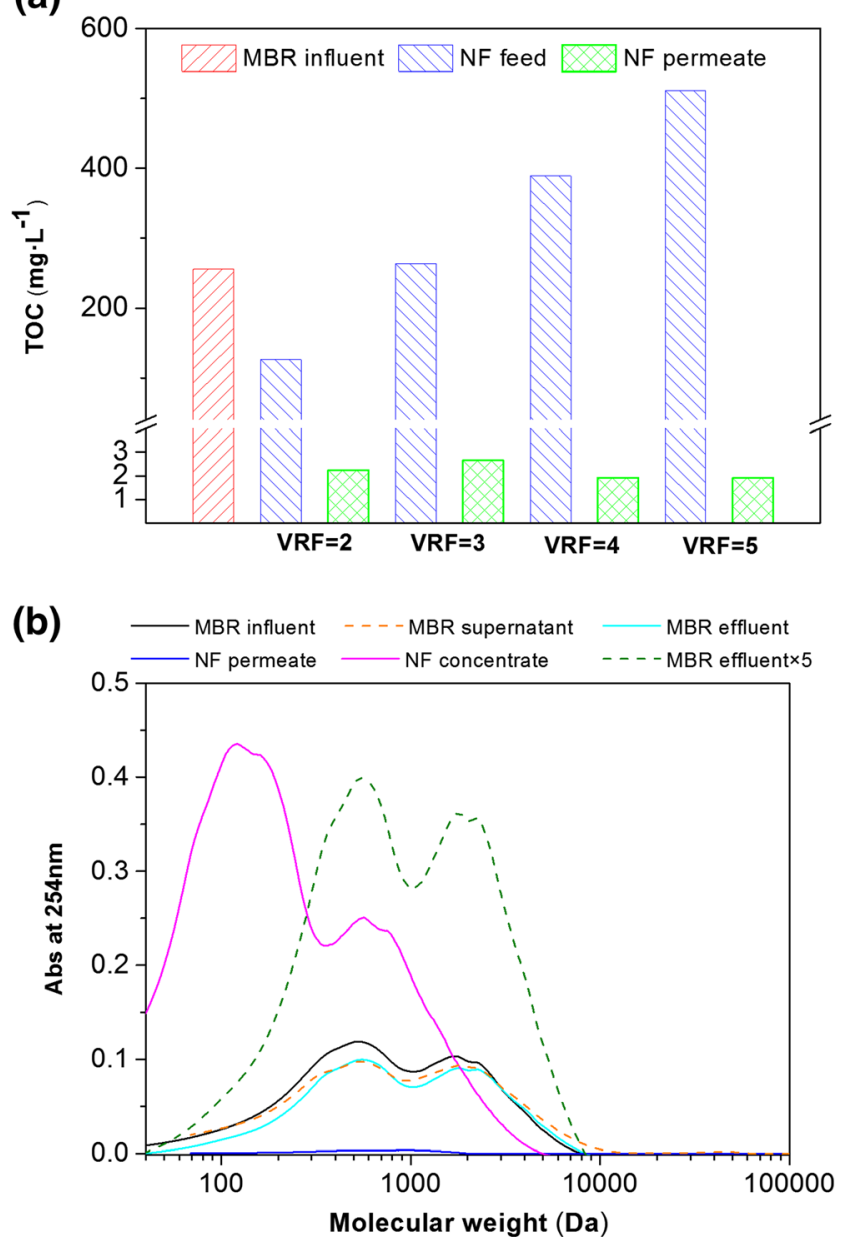

Fig. 5 Fate of organic contaminants in the MBR-NF process: a TOC, b molecular weight distribution $(\mathrm{VRF}=5)$

easier to be degraded by the MBR which proved that the backflow of NF concentrate could enhance the organics removal efficiency of the whole system (Alturki et al. 2010; Chon et al. 2012; Jacob et al. 2010).

\section{D-EEMs}

3D-EEMs is used to identify fluorescent compounds in mixtures (Chen et al. 2003; Rosario-Ortiz et al. 2007). Water samples of MBR and NF were collected for 3D-EEMs test, and results are shown in Fig. 6 and Table S10 (SI). There are four main regions in the peak distribution according to the definition by Chen et al. (2003). MBR influent contained tyrosinelike aromatic proteins (peak A), soluble microbial byproductlike (peak B), and humic acid-like compounds (peak C) came from the antibiotic production wastewater. Protein-like compounds and soluble microbial byproducts could be degraded by activated sludge, while fulvic acid-like compounds (peaks $\mathrm{D}$ and $\mathrm{F}$ ) were excreted in MBR supernatant and MBR effluent. The peak intensity of humic acid-like compounds declined $20.49 \%$ in MBR supernatant and was further declined

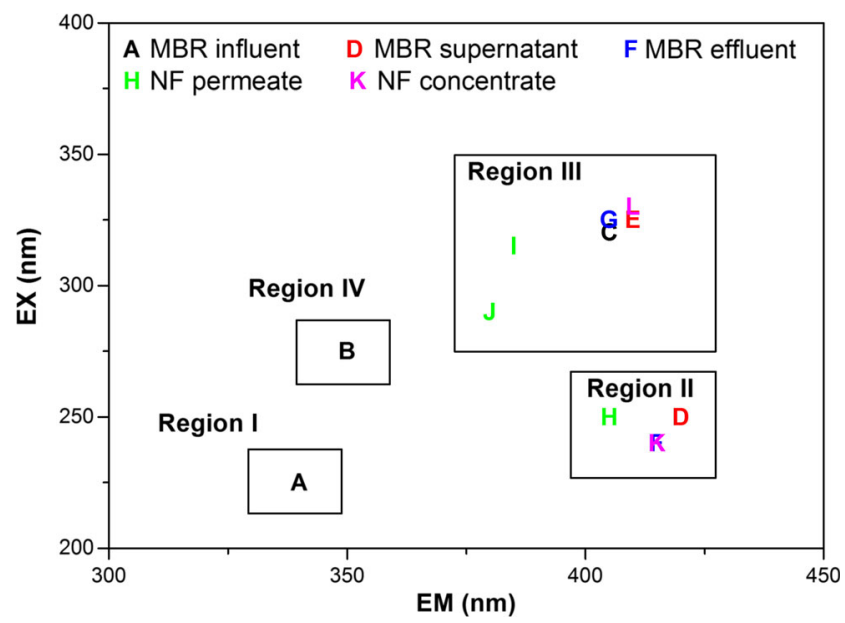

Fig. 6 Peaks distribution of fluorescence spectra in water samples: Region I: tyrosine-like compounds, aromatic proteins; Region II: soluble microbial byproduct-like materials; Region III: fulvic acid-like compounds; Region IV: humic acid-like compounds

by the membrane filtration of MBR. In NF unit, most organic matters were retained and accumulated in NF concentrate which implied that the fulvic acid-like and humic acid-like compounds should be responsible for the serious membrane fouling of NF with the increase of VRF (García-Figueruelo et al. 2008; Jacob et al. 2010).

\section{Conclusions}

A laboratory-scale MBR-NF hybrid system was used for the advanced treatment of antibiotic production wastewater in this study. The NF concentrate was recycled to the MBR to enhance water recovery and pollutants removal of the system. The optimized $R_{\mathrm{cb}}$ at $60 \%$ was achieved based on the performance of MBR on the removals of COD and $\mathrm{NH}_{4}{ }^{+} \mathrm{N}$. Results of Spearman's rank correlation test and PCA demonstrated that the salinity brought by NF concentrate is the key factor that influence the sludge activity, especially at a high $R_{\mathrm{cb}}$. Statistical analysis of EPS in MBR indicated that EC, PN in SMP, and SMP brought by NF concentrate are the main causes leading to the severe membrane fouling in MBR at the $R_{\mathrm{cb}}$ of $90 \%$. NF showed a high COD removal efficiency throughout all periods, and an unsurprising high removal rate for multivalent ions coupled with a relatively low removal rate for monovalent ions. An extremely higher flux decline was observed at the $R_{\mathrm{cb}}$ of $90 \%$ with a VRF up to 4 or 5 , suggesting the rapid fouling of NF. The fate of organic contaminants in the MBR-NF process implied that those relatively lower MW compounds in NF concentrate could be well degraded by MBR, while fulvic acid-like and humic acid-like compounds should be responsible for the serious membrane fouling of NF. Overall, the MBR-NF process showed a relatively stable performance at the $R_{\mathrm{cb}}$ of $60 \%(\mathrm{VRF}=5)$, and the NF 
permeate could meet the water quality standard for fermentation process with a water recovery rate of $90.9 \%$.

\section{Nomenclature}

ANLR Ammonium loading rate ( $\mathrm{kgCOD} \mathrm{kgVSS}{ }^{-1}$ day $^{-1}$ ) bEPS Bound EPS

$C E R$ Cation exchange resin

$C O D$ Chemical oxygen demand $(\mathrm{mg} / \mathrm{L})$

$C M F$ Concentration mode of filtration

$C_{O 2}$ Oxygen concentration $(\mathrm{mg} / \mathrm{L})$

CST Capillarity suction time (s)

Da Daltons

$D O$ Dissolved oxygen $(\mathrm{mg} / \mathrm{L})$

$E C$ Electric conductivity $(\mathrm{mS} / \mathrm{cm})$

EPS Extracellular polymeric substances

$f$ Ratio of MLVSS/MLSS

$F / M$ Food to microorganism ratio $\left(\mathrm{kgCOD} \mathrm{kgVSS}^{-1}\right.$ day $\left.^{-1}\right)$

$G P C$ Gel permeation chromatography

$H P L C$ High performance liquid chromatography

HRT Hydraulic retention time (h)

$J$ Permeate flux (L/( $\left.\left(\mathrm{m}^{2} \mathrm{~s}\right)\right)$

IbEPS Loosely bound EPS

$N F$ Nanofiltration

$M B R-N F$ Membrane bioreactor-nanofiltration

$M F$ Microfiltration

MLSS Mixed liquor suspended solids (mg/L)

MLVSS Mixed liquor volatile suspended solids $(\mathrm{mg} / \mathrm{L})$

$M W$ Molecular weight (Da)

ORLR Organic removal loading rate $\left(\mathrm{kgCOD} \mathrm{kgVSS}^{-1} \mathrm{~d}^{-1}\right)$

$P C$ Polysaccharides

$P C A$ Principal component analysis

$P N$ Proteins

$Q_{\mathrm{c}}$ Flow rate of the NF concentrate produced $(\mathrm{L} / \mathrm{h})$

$Q_{\text {cb }}$ Flow rate of NF concentrate returned (L/h)

$Q_{\mathrm{i}}$ Flow rate of the NF influent $(\mathrm{L} / \mathrm{h})$

$R_{\mathrm{cb}}$ Concentrate backflow ratio (\%)

$R_{\mathrm{Cl}-} \mathrm{Cl}^{-}$removal rate (\%)

$R_{\mathrm{COD}} \mathrm{COD}$ removal rate (\%)

$R_{\mathrm{EC}}$ EC removal rate (\%)

$R_{\mathrm{K}+} \mathrm{K}^{+}$removal rate $(\%)$

$R_{\mathrm{Na}+} \mathrm{Na}^{+}$removal rate $(\%)$

$R_{\mathrm{NH} 4+} \mathrm{NH}_{4}^{+}-\mathrm{N}$ removal rate (\%)

$R O$ Reverse osmosis

$r_{\mathrm{p}}$ Pearson's coefficient

$r_{\mathrm{S}}$ Spearman's coefficient

$R_{\mathrm{t}}$ Filtration resistance $\left(\mathrm{m}^{-1}\right)$

$R_{\mathrm{w}}$ Water recovery rate (\%)

SEM-EDX Scanning electron microscopy with energy dispersive X-ray spectroscopy

SMP Soluble microbial products
SOUR Specific oxygen uptake rate $\left(\mathrm{mgO}_{2} \mathrm{gVSS}^{-1} \mathrm{~h}^{-1}\right)$ specific $S M P_{C}$ Ratio of the polysaccharides between SMP and MLVSS ( $\mathrm{mg} \mathrm{gVSS}^{-1}$ )

specific $b E P S_{C}$ Ratio of the polysaccharides between bEPS and MLVSS (mg gVSS ${ }^{-1}$ )

specific $S M P_{p}$ Ratio of the proteins between SMP and MLVSS (mg gVSS ${ }^{-1}$ )

specific $b E P S_{p}$ Ratio of the proteins between bEPS and MLVSS (mg gVSS ${ }^{-1}$ )

$S R T$ Solid retention time (day)

SI Supplementary information

SS Suspended solids $(\mathrm{mg} / \mathrm{L})$

TDS Total dissolved solids ( $\mathrm{mg} / \mathrm{L}$ )

$3 D$-EEMS Three-dimensional fluorescence excitationemission matrix spectrometry

TMP Transmembrane pressure (bar)

TOC Total organic carbon $(\mathrm{mg} / \mathrm{L})$

$U F$ Ultrafiltration

$V_{\mathrm{c}}$ Volume of the NF concentrate produced (L)

$V_{\mathrm{cb}}$ Volume of NF concentrate returned to the MBR (L)

$V_{\mathrm{f}}$ Initial volume of the NF feed (L)

$V_{\mathrm{p}}$ Final volume of the NF permeate (L)

$V R F$ Volume reduction factor

VSS Volatile suspended solids (mg/L)

\section{Greek symbols}

$\mu$ permeate viscosity (Pa s)

Acknowledgments Financial support provided by National High Technology Research and Development Program of China (no. 2009AA063901) and the National Major Science \& Technology Projects for Water Pollution Control and Management (nos. 2012ZX07203-002 and 2015ZX07203-005), and the Major Breakthrough Projects of Chinese Academy of Sciences (no. ZDTP20140201-001) are gratefully acknowledged.

\section{References}

Al-Halbouni D, Traber J, Lyko S, Wintgens T, Melin T, Tacke D, Janot A, Dott W, Hollender J (2008) Correlation of EPS content in activated sludge at different sludge retention times with membrane fouling phenomena. Water Res 42:1475-1488

Al-Rifai JH, Khabbaz H, Schäfer AI (2011) Removal of pharmaceuticals and endocrine disrupting compounds in a water recycling process using reverse osmosis systems. Sep Purif Technol 77:60-67

Alturki AA, Tadkaew N, McDonald JA, Khan SJ, Price WE, Nghiem LD (2010) Combining MBR and NF/RO membrane filtration for the removal of trace organics in indirect potable water reuse applications. J Membr Sci 365:206-215

Andrade LH, Mendes FDS, Espindola JC, Amaral MCS (2014) Nanofiltration as tertiary treatment for the reuse of dairy wastewater treated by membrane bioreactor. Sep Purif Technol 126:21-29

Baudequin C, Mai ZH, Rakib M, Deguerry I, Severac R, Pabon M, Couallier E (2014) Removal of fluorinated surfactants by reverse 
osmosis - role of surfactants in membrane fouling. J Membr Sci 458:111-119

Cetecioglu Z (2014) Aerobic inhibition assessment for anaerobic treatment effluent of antibiotic production wastewater. Environ Sci Pollut Res 21:2856-2864

Chen W, Westerhoff P, Leenheer JA, Booksh K (2003) Fluorescence excitation-emission matrix regional integration to quantify spectra for dissolved organic matter. Environ Sci Technol 37:5701-5710

Cheng Y, Wei Y, Wang J, Su Y, Li M (2012) Comparison of membrane module performance in flat-sheet membrane bioreactor for treating spiramycin wastewater China. Water \& Wastewater 28:20-24

Cheng SF, Lee YC, Kuo CY, Wu TN (2015) A case study of antibiotic wastewater treatment by using a membrane biological reactor system. Int Biodeterior Biodegrad 102:398-401

Chinese NEPA (2002) Water and wastewater monitoring methods. Chinese Environmental Science Publishing House, Beijing

Cho J, Song KG, Yun H, Ahn KH, Kim J, Chung T (2005) Quantitative analysis of biological effect on membrane fouling in submerged membrane bioreactor. Water Sci Technol 51:9-18

Chon K, KyongShon H, Cho J (2012) Membrane bioreactor and nanofiltration hybrid system for reclamation of municipal wastewater: removal of nutrients, organic matter and micropollutants. Bioresour Technol 122:181-188

Cuartas-Uribe B, Iborra-Clar A, Bes-Piá A, Mendoza-Roca JA, GalianaAleixandre MV, Iborra-Clar MI (2006) Nanofiltration of a simulated tannery wastewater: influence of chlorides concentration. Desalination 191:132-136

Yuan D-q, Wang Y-1 (2012) Study on the stratification components of extracellular polymeric substances (EPS) in activated sludge and their variation characteristics in physicochemical properties. Huanjing Kexue 33:3522-3528

Dubois M, Gilles KA, Hamilton JK, Rebers P, Smith F (1956) Colorimetric method for determination of sugars and related substances. Anal Chem 28:350-356

García-Figueruelo C, Montag B, Bes-Piá A, Mendoza-Roca J, SorianoCosta E, Lora-García J (2008) Study of the behaviour of a reverse osmosis membrane for wastewater reclamation-influence of wastewater concentration. Desalination 222:243-248

Guo B, Gong L, Duan E, Liu R, Ren A, Han J, Zhao W (2012) Characteristics of penicillin bacterial residue. J Air Waste Manage Assoc 62:485-488

Gutierrez M, Etxebarria J, De Las Fuentes L (2002) Evaluation of wastewater toxicity: comparative study between Microtox ${ }^{\circledR}$ and activated sludge oxygen uptake inhibition. Water Res 36:919-924

Han S-S, Bae T-H, Jang G-G, Tak T-M (2005) Influence of sludge retention time on membrane fouling and bioactivities in membrane bioreactor system. Process Biochem 40:2393-2400

Huang Y, Li X, Yang Q, Zeng G, Liu J (2006) Application of advanced oxidation processes to antibiotic wastewater treatment. Industrial Water Treatment 26:13

Huang H, Schwab K, Jacangelo JG (2009) Pretreatment for low pressure membranes in water treatment: a review. Environ Sci Technol 43: 3011-3019

Huang J, Chen J, Xie Z, Xu X (2015) Treatment of nanofiltration concentrates of mature landfill leachate by a coupled process of coagulation and internal micro-electrolysis adding hydrogen peroxide. Environ Technol 36:1001-1007

Jacob M, Guigui C, Cabassud C, Darras H, Lavison G, Moulin L (2010) Performances of $\mathrm{RO}$ and $\mathrm{NF}$ processes for wastewater reuse: tertiary treatment after a conventional activated sludge or a membrane bioreactor. Desalination 250:833-839

Jang D, Moon C, Ahn K, Shin H-S, Hwang Y (2014) Investigation of microbial adaptation to salinity variation for treatment of reverse osmosis concentrate by membrane bioreactor. Desalin Water Treat 56(8):2066-2072
Joss A, Baenninger C, Foa P, Koepke S, Krauss M, McArdell CS, Rottermann K, Wei Y, Zapata A, Siegrist H (2011) Water reuse:> $90 \%$ water yield in $\mathrm{MBR} / \mathrm{RO}$ through concentrate recycling and $\mathrm{CO}_{2}$ addition as scaling control. Water Res 45:6141-6151

Jubany I, Baeza JA, Carrera J, Lafuente J (2005) Respirometric calibration and validation of a biological nitrite oxidation model including biomass growth and substrate inhibition. Water Res 39:4574-4584

Judd S (2010) The MBR book: principles and applications of membrane bioreactors for water and wastewater treatment. Elsevier

Kappel C, Yasadi K, Temmink H, Metz SJ, Kemperman AJB, Nijmeijer K, Zwijnenburg A, Witkamp GJ, Rijnaarts HHM (2013) Electrochemical phosphate recovery from nanofiltration concentrates. Sep Purif Technol 120:437-444

Kappel C, Kemperman AJB, Temmink H, Zwijnenburg A, Rijnaarts HHM, Nijmeijer K (2014) Impacts of NF concentrate recirculation on membrane performance in an integrated MBR and NF membrane process for wastewater treatment. J Membr Sci 453:359-368

Larsson DGJ, de Pedro C, Paxeus N (2007) Effluent from drug manufactures contains extremely high levels of pharmaceuticals. J Hazard Mater 148:751-755

Lau W-J, Ismail AF (2009) Polymeric nanofiltration membranes for textile dye wastewater treatment: preparation, performance evaluation, transport modelling, and fouling control- a review. Desalination 245:321-348

Le-Minh N, Khan SJ, Drewes JE, Stuetz RM (2010) Fate of antibiotics during municipal water recycling treatment processes. Water Res 44 : 4295-4323

Li S (2002) Research on hydrolysis acidification-UASB-AB process treating antibiotic wastewater. Water Wastewater Eng 28:44-49

Li X, Shi H, Li K, Zhang L, Gan Y (2014) Occurrence and fate of antibiotics in advanced wastewater treatment facilities and receiving rivers in Beijing. Front Environ Sci Eng 8:888-894

Lin H, Liao B-Q, Chen J, Gao W, Wang L, Wang F, Lu X (2011) New insights into membrane fouling in a submerged anaerobic membrane bioreactor based on characterization of cake sludge and bulk sludge. Bioresour Technol 102:2373-2379

Liu Y, Liu Z, Zhang A, Chen Y, Wang X (2012) The role of EPS concentration on membrane fouling control: comparison analysis of hybrid membrane bioreactor and conventional membrane bioreactor. Desalination 305:38-43

Liu P, Zhang H, Feng Y, Yang F, Zhang J (2014) Removal of trace antibiotics from wastewater: a systematic study of nanofiltration combined with ozone-based advanced oxidation processes. Chem Eng J 240:211-220

Lowry OH, Rosebrough NJ, Farr AL, Randall RJ (1951) Protein measurement with the Folin phenol reagent. J Biol Chem 193:265-275

Luo JQ, Wan YH (2013) Effects of $\mathrm{pH}$ and salt on nanofiltration-a critical review. J Membr Sci 438:18-28

Meng F, Chae S-R, Drews A, Kraume M, Shin H-S, Yang F (2009) Recent advances in membrane bioreactors (MBRs): membrane fouling and membrane material. Water Res 43:1489-1512

Michael I, Rizzo L, McArdell CS, Manaia CM, Merlin C, Schwartz T, Dagot C, Fatta-Kassinos D (2013) Urban wastewater treatment plants as hotspots for the release of antibiotics in the environment: A review. Water Res 47:957-995

Ordóñez Sanz R, Hermosilla Redondo D, San Pío Tendero I, Blanco Suárez Á (2010) Replacement of fresh water use by final effluent recovery in a highly optimized $100 \%$ recovered paper mill. Water Sci Technol 62:1694-1703

Ordóñez R, Hermosilla D, Pío IS, Blanco Á (2011) Evaluation of MF and UF as pretreatments prior to $\mathrm{RO}$ applied to reclaim municipal wastewater for freshwater substitution in a paper mill: A practical experience. Chem Eng J 166:88-98

Pan JR, Su Y-C, Huang C, Lee H-C (2010) Effect of sludge characteristics on membrane fouling in membrane bioreactors. J Membr Sci 349: $287-294$ 
Rautenbach R, Mellis R (1994) Waste water treatment by a combination of bioreactor and nanofiltration. Desalination 95:171-188

Ravikumar YVL, Kalyani S, Satyanarayana SV, Sridhar S (2014) Processing of pharmaceutical effluent condensate by nanofiltration and reverse osmosis membrane techniques. J Taiwan Inst Chem Eng 45:50-56

Rene ER, Kim SJ, Park HS (2008) Effect of COD/N ratio and salinity on the performance of sequencing batch reactors. Bioresour Technol 99:839-846

Rosario-Ortiz FL, Snyder SA, Suffet I (2007) Characterization of dissolved organic matter in drinking water sources impacted by multiple tributaries. Water Res 41:4115-4128

Salehi F (2014) Current and future applications for nanofiltration technology in the food processing. Food Bioprod Process 92:161-177

Sweity A, Ying W, Ali-Shtayeh MS, Yang F, Bick A, Oron G, Herzberg M (2011) Relation between EPS adherence, viscoelastic properties, and MBR operation: biofouling study with QCM-D. Water Res 45: $6430-6440$

$>$ Uygur A (2006) Specific nutrient removal rates in saline wastewater treatment using sequencing batch reactor. Process Biochem 41:61-66

Van der Bruggen B, Koninckx A, Vandecasteele C (2004) Separation of monovalent and divalent ions from aqueous solution by electrodialysis and nanofiltration. Water Res 38:1347-1353

Van der Bruggen B, Mänttäri M, Nyström M (2008) Drawbacks of applying nanofiltration and how to avoid them: a review. Sep Purif Technol 63:251-263

Wang Z, Wu Z, Yu G, Liu J, Zhou Z (2006) Relationship between sludge characteristics and membrane flux determination in submerged membrane bioreactors. J Membr Sci 284:87-94

Wang Z, Wu Z, Tang S (2009) Extracellular polymeric substances (EPS) properties and their effects on membrane fouling in a submerged membrane bioreactor. Water Res 43:2504-2512

Wang Z, Wu Z, Tang S, Ye S (2011) Role of EPS in membrane fouling of a submerged anaerobic-anoxic-oxic (AAO) membrane bioreactor for municipal wastewater treatment. Desalin Water Treat 34:88-93
Wang JX, Wei YS, Li K, Cheng YT, Li MY, Xu JG (2014) Fate of organic pollutants in a pilot-scale membrane bioreactor-nanofiltration membrane system at high water yield in antibiotic wastewater treatment. Water Sci Technol 69:876-881

Wang JX, Li K, Wei YS, Cheng YT, Wei DB, Li MY (2015) Performance and fate of organics in a pilot MBR-NF for treating antibiotic production wastewater with recycling NF concentrate. Chemosphere 121:92-100

Wei XY, Wang Z, Fan FH, Wang JX, Wang SC (2010) Advanced treatment of a complex pharmaceutical wastewater by nanofiltration: membrane foulant identification and cleaning. Desalination 251: $167-175$

Wu Z, Wang Z, Zhou Z, Yu G, Gu G (2007) Sludge rheological and physiological characteristics in a pilot-scale submerged membrane bioreactor. Desalination 212:152-164

Yaman FB, Cakmakci M, Ozkaya B, Karadag D, Yetilmezsoy K, Dora B, Celebi V (2015) Anaerobic treatment of ozonated membrane concentrate. Desalin Water Treat 54:2075-2081

Yang X-L, Song H-L, Lu J-L, Fu D-F, Cheng B (2010) Influence of diatomite addition on membrane fouling and performance in a submerged membrane bioreactor. Bioresour Technol 101:9178-9184

Ye F, Peng G, Li Y (2011) Influences of influent carbon source on extracellular polymeric substances (EPS) and physicochemical properties of activated sludge. Chemosphere 84:1250-1255

Yogalakshmi K, Joseph K (2010) Effect of transient sodium chloride shock loads on the performance of submerged membrane bioreactor. Bioresour Technol 101:7054-7061

Yu X, Zuo J, Li R, Gan L, Li Z, Zhang F (2014) A combined evaluation of the characteristics and acute toxicity of antibiotic wastewater. Ecotoxicol Environ Saf 106:40-45

Zhang Z-J, Chen S-H, Wang S-M, Luo H-Y (2011) Characterization of extracellular polymeric substances from biofilm in the process of starting-up a partial nitrification process under salt stress. Appl Microbiol Biotechnol 89:1563-1571 